\title{
AKTIVITAS ANTIBAKTERI EKSTRAK DAUN PACAR (Lawsonia Inermis L.)
}

\author{
Nur Masyithah, Z*; Herman, Laode Rijai \\ Laboratorium Penelitian dan Pengembangan FARMAKA TROPIS, Fakultas Farmasi, Universitas Mulawarman, \\ Samarinda, Kalimantan Timur \\ *email: nurmasyithah28@yahoo.com
}

\begin{abstract}
ABSTRAK
Telah dilakukan penelitian Aktivitas Antibakteri Ekstrak Daun Pacar (Lawsonia inermis L.). Pengujian aktivitas antibakteri dilakukan dengan metode difusi agar dengan konsentrasi uji $10 \%, 15 \%$ dan $20 \%$ pada ekstrak metanol dan $1 \%, 5 \%, 10 \%, 15 \%$ dan $20 \%$ pada fraksi $n$ heksana, etil asetat dan $n$-butanol terhadap bakteri uji S.aureus dan P.aeruginosa. Hasil uji aktivitas antibakteri ekstrak daun pacar dengan nilai zona hambat pada konsentrasi $10 \%(3,40$ $\mathrm{mm}$ dan 2,50 $\mathrm{mm}), 15 \%$ (6,48 $\mathrm{mm}$ dan $6,05 \mathrm{~mm}$ ) dan $20 \%$ (2,86 $\mathrm{mm}$ dan 3,18 $\mathrm{mm}$ ). Hasil uji aktivitas antibakteri fraksi $n$-heksana dengan nilai zona hambat pada konsentrasi $1 \%(0,66$ $\mathrm{mm}$ dan $0 \mathrm{~mm}), 5 \%(2,15 \mathrm{~mm}$ dan $1,81 \mathrm{~mm}), 10 \%$ (5,00 $\mathrm{mm}$ dan 3,36 mm), 15\% (4,26 mm dan $1,98 \mathrm{~mm})$ dan $20 \%(3,84 \mathrm{~mm}$ dan $4,60 \mathrm{~mm})$. Hasil uji aktivitas antibakteri fraksi etil asetat dengan nilai zona pada konsentrasi $1 \%(0,57 \mathrm{~mm}$ dan $0,78 \mathrm{~mm}), 5 \% \quad(3,61 \mathrm{~mm}$ dan $2,80 \mathrm{~mm}), 10 \%(6,99 \mathrm{~mm}$ dan $5,82 \mathrm{~mm}), 15 \%(4,83 \mathrm{~mm}$ dan $6,75 \mathrm{~mm})$ dan $20 \%(4,84 \mathrm{~mm}$ dan 5,23 mm). Hasil uji aktivitas antibakteri fraksi $n$-butanol dengan nilai zona hambat pada konsentrasi $1 \%$ (0 mm dan $0 \mathrm{~mm}), 5 \%$ (7,00 mm dan 1,91 $\mathrm{mm}), 10 \%$ (5,87 $\mathrm{mm}$ dan 4,71 $\mathrm{mm}), 15 \%(8,57 \mathrm{~mm}$ dan $6,08 \mathrm{~mm})$ dan $20 \%(6,69$ dan 4,82 mm). Kontrol negatif aquades tidak menunjukkan adanya aktivitas antibakteri.
\end{abstract}

Kata kunci : Antibakteri, Lawsonia inermis L.

\section{PENDAHULUAN}

Jasad renik merupakan penyebab penyakit tertentu, banyak perhatian ditujukan kepada pengembangan cara-cara untuk pencegahan dan pengobatan terhadap penyakit tersebut. Penyebab etiologis (agen kausatif) untuk sebagian besar penyakit bakterial yang dikenal masa kini (Pelczar dan Chan, 2008). Pemanfaatan bahan alam sebagai obat merupakan hal tepat yang dapat menunjang kehidupan, dimana beberapa keuntungan dari bahan-bahan alami yaitu salah satunya memiliki efek samping rendah apabila dibandingkan dengan obat dari bahan sintetik. Antibiotik merupakan salah satu obat dengan efek samping yang tinggi apabila dibuat secara sintetik, hal ini yang menjadi dasar pemikiran untuk mengkaji dan meneliti berbagai tumbuhan yang memiliki aktivitas sebagai antibakteri.

Tumbuhan yang diduga berpotensi sebagai antibakteri salah satunya tumbuhan pacar (Lawsonia inermis L.). Daun pacar memiliki banyak khasiat diantaranya yaitu sebagi peluruh haid dan obat keputihan, dengan kandungan senyawa metabolit sekunder saponin, flavonoid dan tanin (Depkes RI, 2001). Daun pacar mengandung senyawa fenol berkhasiat sebagai antijamur, antibakteri dan mengobati penyakit kuning (Cahyani,2001). Khasiat daun pacar lainnya yaitu astringent, anodyne, antiinflamasi, anti jamur, antibakteri, depurative, diuretic, muntah, ekspektoran, obat penurun panas, pendingin, obat penahan darah dan 
vulnerary (Lee, 2008). P.aeruginosa merupakan mikroorganisme yang paling umum ditemukan pada usus besar. Kebanyakan mikroorganisme yang tumbuh dalam saluran usus besar masih dikategorikan sebagai bakteri oportunis. S.aureus merupakan mikroorganisme dengan populasi paling besar pada kulit, yang dapat menginfeksi manusia terutama pada membrane mukosa daerah nasal, Infeksi lokal S.aureus muncul sebagai suatu pimple, infeksi folikel rambut, atau abses (Djide, 2008). Infeksi S.aureus juga dapat disebabkan oleh kontaminasi langsung pada luka, misalnya pada infeksi luka pasca bedah atau infeksi setelah trauma (Jawets, 2005). Secara empiris daun pacar digunakan oleh masyarakat yaitu sebagai obat luka dan obat diare, dimana penyebab dari luka dan diare yaitu infeksi oleh bakteri. Salah satu bakteri yang mampu menginfeksi luka yaitu S.aureus yang merupakan flora normal di kulit, dan salah satu bakteri penyebab diare yaitu $P$.aeruginosa yang merupakan bakteri flora normal di usus besar. Penelitian ini menguji aktivitas antibakteri ekstrak daun pacar (Lawsonia inermis L.) terhadap bakteri S.aureus dan P.aeruginosa.

\section{METODE PENELITIAN}

\section{Bahan}

Daun pacar (Lawsonia inermis L.) diambil dari desa Lempake Jaya, Kecamatan Samarinda Utara, Kota Samarinda pada bulan September 2012. Ekstraksi dengan metode maserasi, $150 \mathrm{~g}$ simplisia daun pacar direndam di dalam pelarut metanol sebanyak 2,5 L dengan menggunakan toples kaca. Perendaman dilakukan selama 5 hari. Setelah 5 hari dilakukan penyaringan sehingga diperoleh larutan ekstrak metanol daun pacar. Larutan ekstrak metanol daun pacar dilakukan penguapan pelarut metanol dengan rotary evaporator, sehingga diperoleh ekstrak kental metanol daun pacar. Selanjutnya dilakukan penguapan sisa pelarut dengan water bath dan desikator sehingga diperoleh ekstrak kering metanol daun pacar. Fraksinasi dengan metode fraksinasi cair-cair dengan pelarut $n$-heksana, etil asetat dan $n$-butanol. ekstrak kering sebanyak $10 \mathrm{~g}$ dilarutkan dengan aquades sebanyak $100 \mathrm{~mL}$, dimasukkan corong pisah, ditambahkan $100 \mathrm{~mL} n$-heksana, didiamkan hingga terpisah menjadi 2 lapisan kemudian diambil larutan ekstrak fraksi $n$-heksana pada lapisan bagian atas lalu dilakukan penguapan dengan water bath dan desikator hingga jadi ekstrak fraksi kering, proses dilakukan maksimal hingga larutan ekstrak metanol bening. Prosedur di atas selanjutnya serupa dilakukan pada pelarut etil asetat dan $n$ butanol. Bahan pengujian aktivitas antibakteri berupa suspensi bakteri uji S.aureus dan P.aeruginosa suspensi bakteri yang digunakan pada pengenceran 1:40, medium NA (Nutrient Agar) yang terdiri dari serbuk pepton, serbuk ekstrak beef dan serbuk agar, $\mathrm{NaCl}$ 0,9\%, alkohol dll.

\section{Peralatan}

Alat-alat yang digunakan pada penelitian ini meliputi, peralatan listrik berupa water bath, rotary evaporator, desikator, vakum, autoklaf, inkubator, oven dan LAF (Laminar Air Flow). Peralatan kaca berupa corong pisah, toples kaca, cawan petri, tabung reaksi, botol pengencer, erlenmeyer dan labu ukur. Peralatan non kaca berupa spoit injeksi, ose bulat, pinset dan sendok tanduk.

\section{Prosedur Pengujian Antibakteri}

Pengujian aktivitas antibakteri, terlebih dahulu dilakukan sterilisasi alat dan bahan yang akan digunakan dalam autoklaf pada suhu $121{ }^{\circ} \mathrm{C}$. Media pembenihan NA 
dibuat dengan cara melarutkan 3,75 gram bubuk ekstrak agar gram, 1,25 gram bubuk ekstrak pepton dan 0,75 bubuk ekstrak beef dalam $250 \mathrm{~mL}$ aquades kemudian diaduk dan dipanaskan hingga larut. Media tersebut disterilkan dengan autoklaf terlebih dahulu sebelum digunakan. Bakteri uji ditanamkan di atas permukaan agar miring yang telah memadat dalam tabung reaksi dan diinkubasikan pada inkubator selama 24 jam pada suhu $37^{\circ} \mathrm{C}$. Setelah 24 jam bakteri uji dilakukan pengenceran dengan ditambahnkan $\mathrm{NaCl}$ 0,9\% hingga di dapatkan pengenceran bakteri uji 1:40. Aktivitas antibakteri ekstrak daun pacar dilakukan dengan metode difusi agar dengan menggunakan medium padat NA (Nutrient agar). Suspensi bakteri dari pengenceran suspensi bakteri 1:40 sebanyak $0,02 \mathrm{~mL}$ dicampur dengan $10 \mathrm{~mL}$ medium NA (Nutrient agar) dalam keadaan hangat, digojog agar homogen kemudian dituang ke dalam cawan petri. Ditunggu beberapa saat hingga medium padat. Papperdisk $(5 \mathrm{~mm})$ di celupkan didalam larutan uji ekstrak daun pacar didiamkan beberapa saat, lalu diletakkan di atas permukaan medium NA (Nutrient agar) yang telah padat, dan diinkubasi pada suhu $37{ }^{\circ} \mathrm{C}$ selama 24 jam. Kontrol negatif digunakan paperdisk yang telah dicelupkan didalam aquades sebagai pelarut ekstrak daun pacar.

\section{HASIL DAN PEMBAHASAN}

Hasil penelitian menunjukkan bahwa larutan uji ekstrak daun pacar memiliki aktivitas antibakteri terhadap bakteri S.aureus dan P.aeruginosa yang diatandai dengan adanya daya hambat di sekitar paperdisk. Kontrol negatif yaitu aquades digunakan sebagai pembanding untuk membuktikan bahwa ada tidaknya aktivitas antibakteri pada ekstrak daun pacar. Kontrol negatif yaitu pelarut ekstrak daun pacar yang digunakan adalah aquades tidak terbentuk zona hambat di sekitar paperdisk sehingga membuktikan ekstrak daun pacar memiliki aktivitas antibakteri. Pengujian aktivitas aktibakteri dilakukan dengan berbagai tingkat konsentrasi, konsentrasi yang digunakan yaitu $10 \%, 15 \%$ dan $20 \%$ pada ekstrak metanol dan 1\%, 5\%, 10\%, $15 \%$ dan $20 \%$ pada fraksi $n$-heksana, etil asetat dan $n$-butanol.

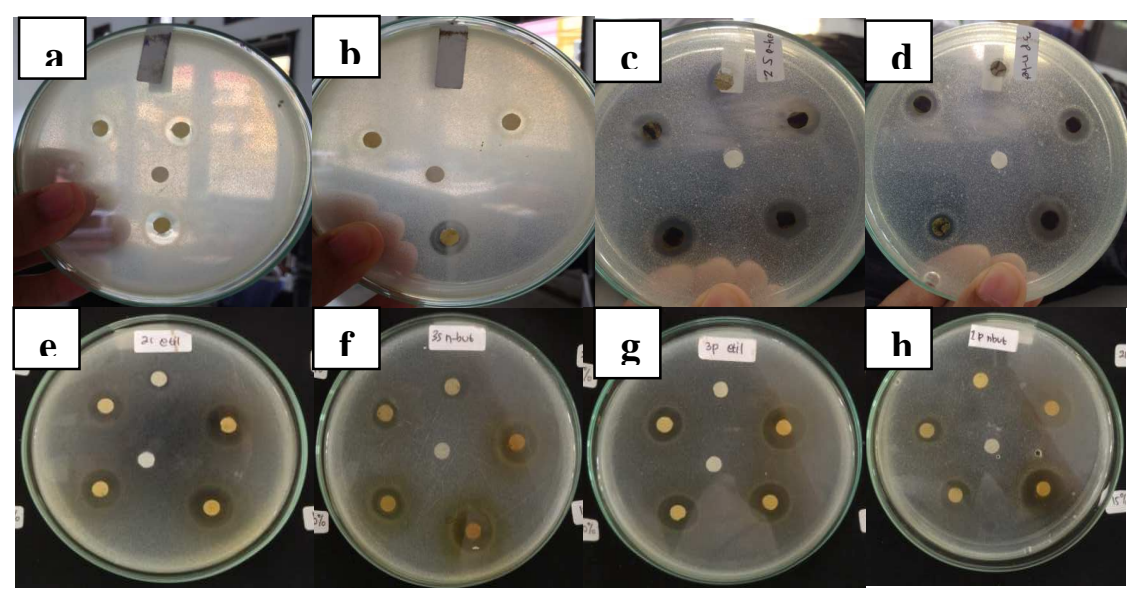

Gambar 1. Uji antibakteri ekstrak dan fraksi daun pacar terhadap bakteri S.aureus dan P.aeruginosa. Keterangan :

a: Ekstrak metanol terhadap bakteri S.aureus,

c: Fraksi n-heksana terhadap bakteri S.aureus,

b: Ekstrak metanol terhadap bakteri P.aeruginosa, $d$ : Fraksi n-heksana terhadap bakteri P.aeruginosa $e$ : Fraksi etil asetat terhadap bakteri S.aureus, g: Fraksi n-butanol terhadap bakteri S.aureus, 
Tabel 1 . Data Zona Bening Ekstrak dan Fraksi Daun Pacar (Lawsonia inermis L.)

\begin{tabular}{|c|c|c|c|c|c|c|}
\hline \multirow[b]{2}{*}{ No. } & \multirow[b]{2}{*}{ Bakteri Uji } & \multirow[b]{2}{*}{ Konsentrasi } & \multicolumn{4}{|c|}{ Rerata diameter Zona bening (mm) } \\
\hline & & & $\begin{array}{l}\text { Ekstrak } \\
\text { Metanol }\end{array}$ & $\begin{array}{c}\text { Fraksi } \\
n \text {-heksana }\end{array}$ & $\begin{array}{c}\text { Fraksi etil } \\
\text { asetat }\end{array}$ & $\begin{array}{c}\text { Fraksi } \\
n \text {-butanol }\end{array}$ \\
\hline \multirow[t]{8}{*}{1} & S.aureus & $10 \%$ & 3,40 & - & - & - \\
\hline & & $15 \%$ & 6,48 & - & - & - \\
\hline & & $20 \%$ & 2,86 & - & - & - \\
\hline & & $1 \%$ & - & 0,66 & 0,57 & - \\
\hline & & $5 \%$ & - & 2,15 & 3,61 & 7,00 \\
\hline & & $10 \%$ & - & 5,00 & 6,99 & 5,87 \\
\hline & & $15 \%$ & - & 4,26 & 4,83 & 8,57 \\
\hline & & $20 \%$ & - & 3,84 & 4,84 & 6,69 \\
\hline \multirow[t]{9}{*}{2.} & P.aeruginosa & $10 \%$ & 2,50 & - & - & - \\
\hline & & $15 \%$ & 6,05 & - & - & - \\
\hline & & $20 \%$ & 3,18 & - & - & - \\
\hline & & $1 \%$ & - & - & 0,78 & - \\
\hline & & $5 \%$ & - & 1,81 & 2,80 & 1,91 \\
\hline & & $10 \%$ & - & 3,36 & 5,82 & 4,71 \\
\hline & & $15 \%$ & - & 1,98 & 6,75 & 6,08 \\
\hline & & $20 \%$ & - & 4,60 & 5,23 & 4,82 \\
\hline & Aquades & - & - & - & - & - \\
\hline
\end{tabular}

Kemampuan senyawa antibakteri dalam menghambat pertumbuhan bakteri dipengaruhi oleh kestabilan terhadap protein, lipid, garam dan tingkat keasaman $(\mathrm{pH})$ dalam medium pertumbuhan. Gambar 1 menunjukkan adanya perbedaan efek antibakteri dari masing-masing ekstrak dan fraksi dimana, pada fraksi $n$-butanol dan etil asetat memiliki aktivitas antibakteri lebih dominan dibandingkan fraksi $n$ heksan dan terhadap bakteri uji, ini diduga senyawa yang terkandung didalam ekstrak daun pacar bersifat polar sehingga senyawa antibakteri yang terkandung didalam fraksi $n$-butanol dan etil asetat. Data yang menunjukkan adanya perbedaan zona bening yang terbentuk disajikan pada Tabel 1. Perbedaan aktivitas antibakteri dari masing-masing ekstrak dan fraksi pada Tabel $1 \mathrm{di}$ atas ditandai dengan perbedaan dari nilai diameter zona bening yang diperoleh. Perbedaan besarnya daya hambat pada masing-masing ekstrak diduga dipengaruhi oleh viskositas ekstrak yang dapat mempengaruhi kecepatan difusi senyawa antibakteri pada media agar dimana semakin tinggi viskositas maka proses difusi zat antibakteri kedalam media agar semakin rendah. Diameter zona bening yang telah diukur dengan menggunakan mikrometer skrup dapat dikategorikan sesuai kekuatan dari aktivitas antibakteri ekstrak dan fraksi daun pacar. Priyatmoko, W. 2008 dalam (Bell 1984) menjelaskan bahwa antimikroba dikatakan mempunyai aktivitas yang tinggi terhadap mikroba apabila nilai konsentrasi minimum hambatannya rendah tetapi mempunyai daya hambat besar. Aktivitas antimikroba ditentukan dengan mengukur diameter hambatannya, yaitu daerah bening yang terbentuk di sekitar kertas cakram. Suatu bahan dikatakan mempunyai akivitas antibakteri apabila diameter hambatan yang terbentuk lebih besar atau sama dengan $6 \mathrm{~mm}$. Priyatmoko, W. 2008 dalam (Davidstout 1971) menjelaskan bahwa suatu antibakteri/antibiotik dikatakan 
mempunyai aktivitas terhadap bakteri jika mempunyai ketentuan kekuatan sebagai berikut, luas daerah hambatan $20 \mathrm{~mm}$ atau lebih masuk kategori sangat kuat, daerah hambatan antara 10-20 mm masuk kategori kuat, daerah hambatan antara 5-10 mm masuk kategori sedang dan daerah hambatan $5 \mathrm{~mm}$ atau kurang masuk kategori lemah. Hasil uji antibakteri ekstrak daun pacar dapat dilihat pada Tabel 1 berikut Hasil uji aktivitas antibakteri ekstrak metanol, fraksi $n$-heksan, fraksi etil asetat dan fraksi $n$-butanol daun pacar menunjukkan adanya aktivitas antibakteri dengan nilai zona bening lebih dari atau sama dengan $6 \mathrm{~mm}$. Perbandingan zona hambat (zona bening) dari masing-masing ekstrak metanol daun pacar terhadap bakteri S.aureus dan P.aeruginosa dapat dilihat pada Gambar 1.

Berdasarkan Gambar 1. mengacu pada Tabel 1 bahwa nilai zona hambat ekstrak metanol daun pacar terhadap bakteri S.aureus dan P.aeruginosa. Hasil uji aktivitas antibakteri ekstrak metanol dengan nilai zona hambat pada konsentrasi $10 \%(3,40 \mathrm{~mm}$ dan $2,50 \mathrm{~mm})$ aktivitas antibakteri termasuk dalam kategori lemah, $15 \%(6,48 \mathrm{~mm}$ dan $6,05 \mathrm{~mm})$ aktivitas antibakteri termasuk dalam kategori sedang dan 20\% (2,86 $\mathrm{mm}$ dan 3,18 $\mathrm{mm})$ aktivitas antibakteri termasuk dalam kategori lemah. Perbedaan besarnya daya hambat pada masing-masing ekstrak metanol daun pacar diduga dipengaruhi oleh viskositas ekstrak metanol yang dapat mempengaruhi kecepatan difusi senyawa antibakteri pada media agar. Perbandingan zona hambat (zona bening) dari masing-masing fraksi $n$ heksana daun pacar terhadap bakteri S.aureus dan P.aeruginosa dapat dilihat pada Gambar 2.

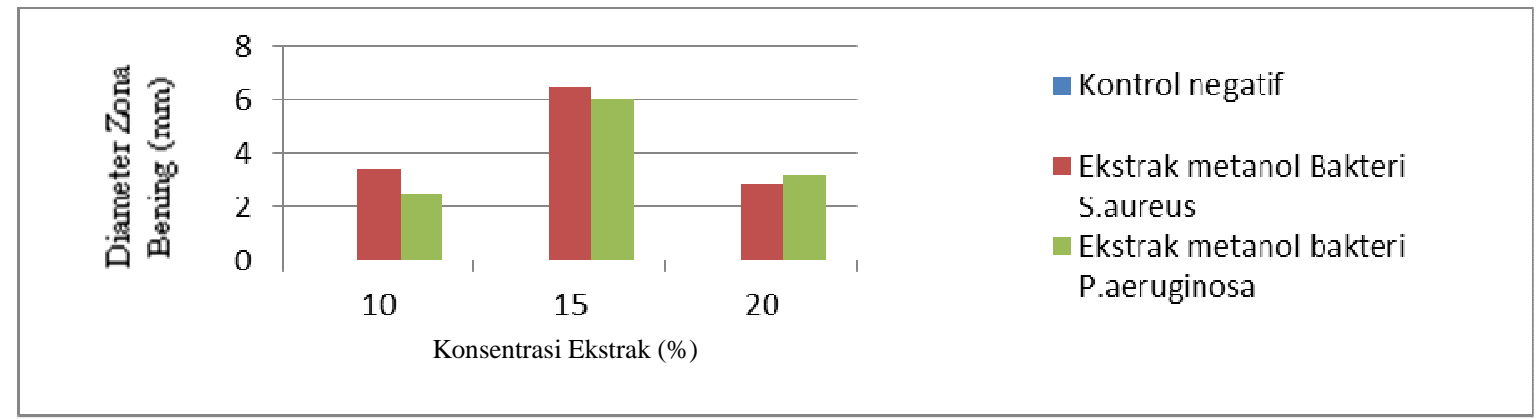

Gambar 1. Perbandingan zona hambat ekstrak metanol DP terhadap bakteri S.aureus dan P.aeruginosa.

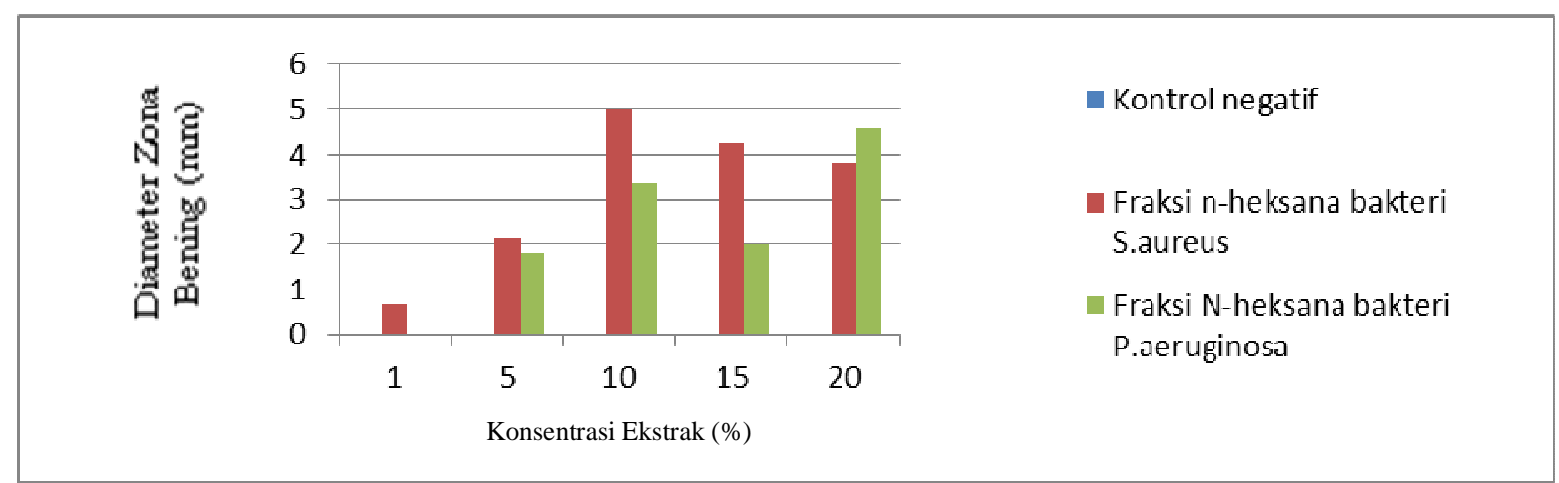

Gambar 2. Perbandingan zona hambat fraksi n-heksana DP terhadap bakteri S.aureus dan P.aeruginosa. 
Berdasarkan Gambar 2 mengacu pada Tabel 1 bahwa nilai zona hambat fraksi nheksana daun pacar terhadap bakteri S.aureus dan P.aeruginosa. Hasil uji aktivitas antibakteri fraksi $n$-heksana dengan nilai zona hambat pada konsentrasi $1 \%(0,66 \mathrm{~mm}$ dan $0 \mathrm{~mm})$ aktivitas antibakteri termasuk dalam kategori lemah, $5 \%(2,15 \mathrm{~mm}$ dan $1,81 \mathrm{~mm})$ aktivitas antibakteri termasuk dalam kategori lemah, $10 \%(5,00 \mathrm{~mm}$ dan $3,36 \mathrm{~mm})$ aktivitas antibakteri termasuk dalam kategori lemah, $15 \%(4,26 \mathrm{~mm}$ dan $1,98 \mathrm{~mm})$ aktivitas antibakteri termasuk dalam kategori lemah dan 20\% (3,84 $\mathrm{mm}$ dan 4,60 $\mathrm{mm})$ aktivitas antibakteri termasuk dalam kategori lemah. Perbedaan besarnya daya hambat pada masing-masing fraksi n-heksana diduga dipengaruhi oleh viskositas fraksi $n$ heksana yang dapat mempengaruhi kecepatan difusi senyawa antibakteri pada media agar. Perbandingan zona hambat (zona bening) dari masing-masing fraksi etil asetat daun pacar terhadap bakteri S.aureus dan P.aeruginosa dapat dilihat pada Gambar 3.

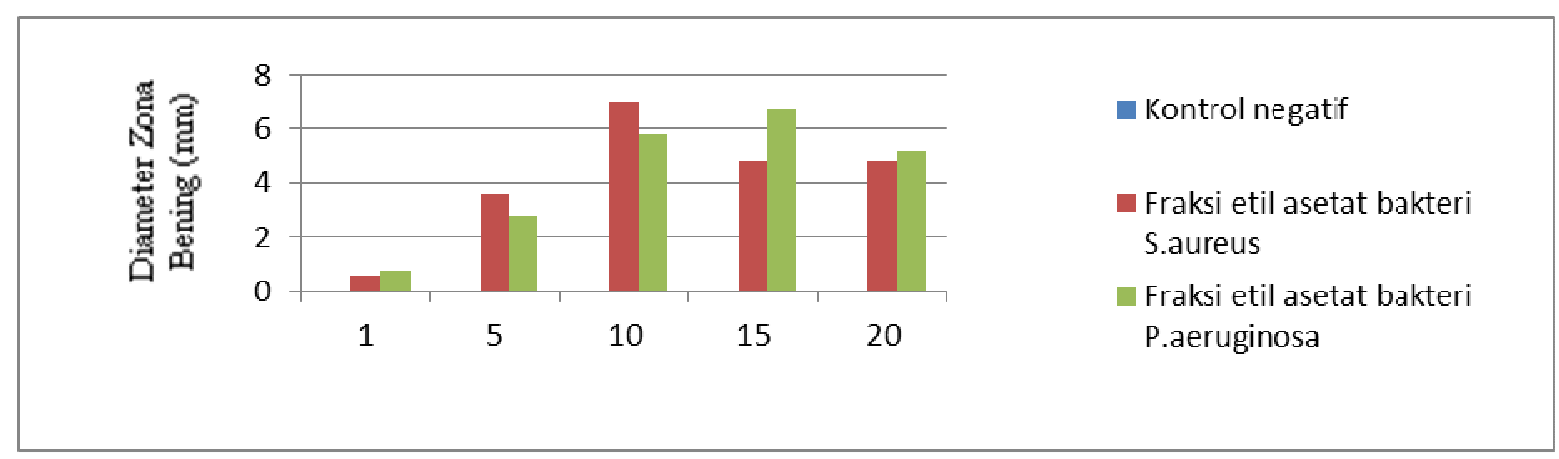

Gambar 3. Perbandingan zona hambat Fraksi etil asetat Daun Pacar terhadap bakteri S.aureus dan P.aeruginosa.

Berdasarkan Gambar 3 mengacu pada Tabel 1 bahwa nilai zona hambat fraksi etil asetat daun pacar terhadap bakteri S.aureus dan P.aeruginosa. Hasil uji aktivitas antibakteri fraksi etil asetat dengan nilai zona pada konsentrasi $1 \%(0,57 \mathrm{~mm}$ dan $0,78 \mathrm{~mm}$ ) aktivitas antibakteri termasuk dalam kategori lemah, $5 \% \quad(3,61 \mathrm{~mm}$ dan 2,80 $\mathrm{mm}$ ) aktivitas antibakteri termasuk kategori lemah, $10 \%(6,99 \mathrm{~mm}$ dan 5,82 $\mathrm{mm})$ aktivitas antibakteri termasuk dalam kategori sedang, $15 \%(4,83 \mathrm{~mm}$ dan 6,75 $\mathrm{mm})$ aktivitas antibakteri terhadap bakteri uji S.aureus tarmasuk dalam kategori lemah sedangkan terhadap bakteri uji P.aeruginosa termasuk dalam kategori sedang dan $20 \%(4,84 \mathrm{~mm}$ dan $5,23 \mathrm{~mm})$ aktivitas antibakteri termasuk dalam kategori lemah. Perbedaan besarnya daya hambat pada masing-masing fraksi etil asetat diduga dipengaruhi oleh viskositas fraksi etil asetat yang dapat mempengaruhi kecepatan difusi senyawa antibakteri pada media agar. Perbandingan zona hambat (zona bening) dari masing-masing fraksi $n$ butanol daun pacar terhadap bakteri S.aureus dan P.aeruginosa dapat dilihat pada Gambar 4. 


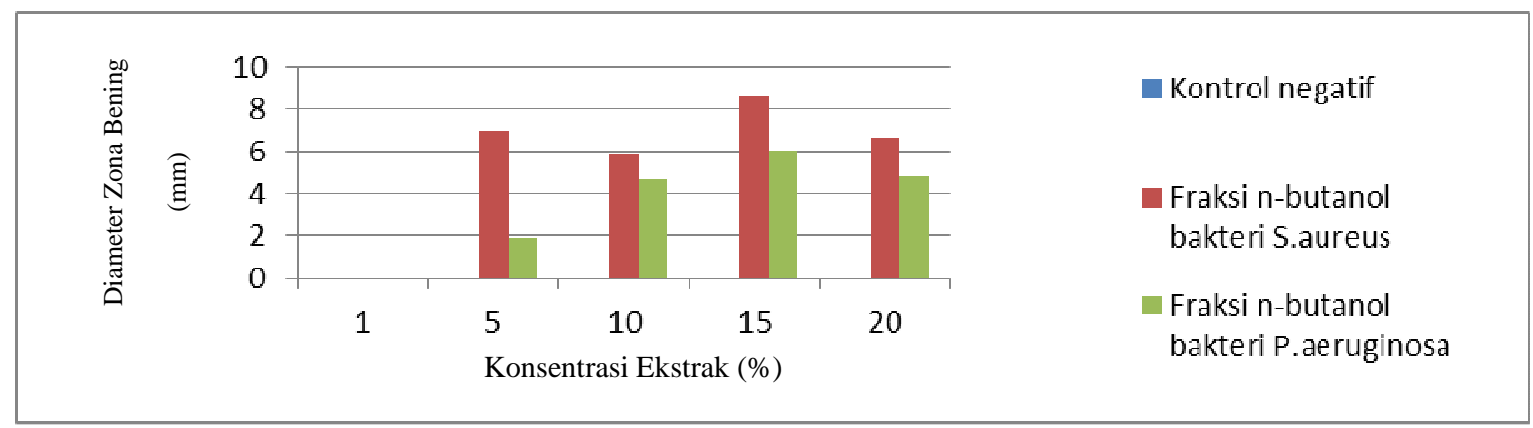

Gambar 4. Perbandingan zona hambat (zona bening) Fraksi n-butanol daun pacar terhadap bakteri

P.aeruginosa.

Berdasarkan Gambar 4 mengacu pada Tabel 1 bahwa nilai zona hambat fraksi $n$ butanol daun pacar terhadap bakteri S.aureus dan P.aeruginosa. Hasil uji aktivitas antibakteri fraksi $n$-butanol dengan nilai zona hambat pada konsentrasi $1 \% \quad(0 \mathrm{~mm}$ dan $0 \mathrm{~mm})$ tidak adanya aktivitas antibakteri, 5\% (7,00 $\mathrm{mm}$ dan $1,91 \mathrm{~mm})$ aktivitas antibakteri termasuk kategori sedang terhadap bakteri uji S.aureus sedangkan terhadap bakteri uji P.aeruginosa termasuk dalam kategori lemah, $10 \% \quad(5,87 \mathrm{~mm}$ dan 4,71 $\mathrm{mm})$ aktivitas antibakteri termasuk dalam kategori lemah, $15 \%(8,57 \mathrm{~mm}$ dan 6,08 $\mathrm{mm})$ aktivitas antibakteri termasuk dalam kategori sedanga dan $20 \%$ (6,69 dan 4,82 $\mathrm{mm})$ aktivitas antibakteri termasuk kategori sedang terhadap bakteri uji S.aureus sedangkan terhadap bakteri uji P.aeruginosa termasuk dalam kategori lemah. Perbedaan besarnya daya hambat pada masing-masing ekstrak metanol daun pacar diduga dipengaruhi oleh viskositas ekstrak yang dapat mempengaruhi kecepatan difusi senyawa antibakteri pada media agar.
Perbedaan aktivitas antibakteri dari masing-masing ekstrak dan fraksi yang ditandai dengan perbedaan dari diameter zona bening yang diperoleh. Perbedaan besarnya daya hambat pada masing-masing ekstrak diduga dipengaruhi oleh viskositas ekstrak yang dapat mempengaruhi kecepatan difusi senyawa antibakteri pada media agar. Hal ini dapat dilihat dan dihubungkan dengan konsentrasi uji yang digunakan yaitu dari kenaikan grafik pada konsentrasi ekstrak dan fraksi daun pacar yang diduga bahwa jumlah zat terlarut optimal sehingga proses difusi ke media agar maksimal. Hal ini menyebabkan daya hambat ekstrak terhadap bakteri uji semakin kuat. Sedangkan pada penurunan grafik konsentrasi ekstrak dan fraksi yang menandakan bahwa kemungkinan dipengaruhi oleh viskositas ekstrak yang dapat mempengaruhi kemampuan berdifusi ekstrak kedalam media agar sehingga mempengaruhi daya hambat, dimana semakin tinggi viskositas maka proses difusi zat antibakteri kedalam media agar semakin rendah. Konsentrasi ekstrak daun pacar yang memiliki aktivitas antibakteri lebih baik dapat dilihat pada Tabel 2 .

Tabel 2. Konsentrasi uji yang memiliki aktivitas antibakteri terbaik pada ekstrak dan fraksi daun pacar.

\begin{tabular}{ccc}
\hline \multirow{2}{*}{ Ekstrak } & Konsentrasi uji yang lebih baik sebagai antibakteri \\
\cline { 2 - 3 } & S.aureus & P.aeruginosa \\
\hline Ekstrak metanol & $15 \%$ & $15 \%$ \\
Fraksi $n$-heksana & $10 \%$ & $10 \%$ \\
Fraksi etil asetat & $10 \%$ & $15 \%$ \\
Fraksi $n$-butanol & $15 \%$ & $15 \%$ \\
\hline
\end{tabular}


Konsentrasi uji dari ekstrak dan fraksi daun pacar yang lebuh baik sebagai antibakteri terlihat pada Tabel 2 bahwa pada pengujian didapatkan konsentrasi puncak dimana ekstrak dan fraksi daun pacar memiliki aktivitas terbaik sebagai antibakteri terhadap bakteri uji S.aureus dan P.aeruginosa ditandai dengan terjadi penurunan aktivitas pada konsentrasi uji berikutnya. Hasil penelitian menunjukkan bahwa ekstrak daun pacar lebih dominan dengan mudah membunuh bakteri gram positif dibandingkan bakteri gram negatif, hal ini kemingkinan dapat disebabkan oleh perbedaan dari komponen sel bakteri gram positif dan gram negatif.

Bakteri gram positif mengandung $40-50 \%$ peptidoglikan serta lapisan tipis asam theikoat dan asam teikuronat yang bermuatan negatif. Sedangkan pada bakteri gram negatif terdapat lapisan di luar dinding sel yang mengandung 5-20\% peptidoglikan. Pada bakteri gram positif tidak terdapat lapisan lipopolisakarida sehingga molekul senyawa antimikroba yang bersifat hidrofilik maupun hidrofobik dapat melewatinya dengan cara difusi pasif. Kemudian akan berinteraksi dengan protein pada lapisan peptidoglikan sehingga menyebabkan kerusakan dinding sel. Hal ini kemudian akan menyebabkan bakteri mengalami lisis akibat tekanan osmotik yang tinggi dari dalam sel.

Bakteri gram negatif terdapat lapisan lipopolisakarida yang menghambat senyawa antibakteri. Kemudian terjadi akumulasi yang kemudian mengganggu ikatan-ikatan hidrofolik (polar) membran luar. Secara selektif sebagian dari senyawa antibakteri dengan ukuran molekul kecil masuk melalui protein porin hingga menuju sitoplasma (Djide, 2008).

\section{KESIMPULAN}

Ekstrak daun pacar (Lawsonia inermis L.) memiliki aktivitas antibakteri terhadap bakteri S.aureus dan P.aeruginosa.

\section{DAFTAR PUSTAKA}

1. Cahyani, N.F. 2001. Studi Efektivitas Daun Pacar (Lawsonia Inermis) Sebagai Alternatif Pewarna Pada Kain Batik. Fakultas Teknik UMS; Surakarta.

2. Depkes RI. 2001. Inventaris Tanaman Obat Indonesia (I) Jilid 2. Bakti Husada; Jakarta.

3. Djide, N.; \& Sartini. 2008. Analisis Mikrobiologi Farmasi. Laboratorium Mikrobiologi Farmasi Fakultas Farmasi Universitas Hasanuddin: Makassar

4. Jawetz. E.; Melnick, J.L.; \& Adelberg, E.A. 2005. Mikrobiologi Kedokteran. Terjemahan Huriati dan Hartanto. Penerbit Buku Kedokteran EGC, Jakarta.

5. Lee, D.F. 2008. Traditional Kitchen Herb Gardens In South India. The International Register of Consultant Herbalists and Homeopaths; India.

6. Priyatmoko, W. 2008. Aktivitas Antibakteri Karang Lunak Hasil Transplantasi (Sinularia Sp.) Pada Dua Kedalaman Berbeda Di Perairan Pulau Pramuka Kepulauan Seribu, DKI Jakarta. Fakultas Perikanan Dan Ilmu Kelautan Institut Pertanian Bogor; Bogor. 